\title{
PEMANFAATAN APLIKASI “GEMBIRA" UNTUK MELATIH KEPEKAAN BUNYI DAN SUARA BAGI SISWA TUNARUNGU
}

\author{
Ade Putri Sarwendah \\ SLB Negeri Balikpapan \\ Email: adeputri9@gmail.com
}

(Diterima: 10 Oktober 2020; Disetujui: 5 Desember 2020; Publikasi: 31 Desember 2020)

\begin{abstract}
Abstrak
Pembelajaran program kompensatoris bagi siswa tunarungu yakni Pengembangan Komunikasi Persepsi Bunyi dan Irama (PKPBI) ditujukan untuk mengoptimalkan potensi siswa tunarungu berupa kepekaan sisa pendengaran dan kepekaan vibrasi. Sebagai upaya melatih siswa tunarungu dalam mengoptimalkan kepekaan sisa pendengaran, dibutuhkan media pembelajaran yang kreatif, salah satunya dengan Aplikasi GEMBIRA (Mengenal Ragam Bunyi dan Suara). Penelitian ini bertujuan untuk mengetahui pemanfaatan Aplikasi GEMBIRA dalam melatih kepekaan terhadap bunyi dan suara bagi siswa tunarungu jenjang sekolah dasar kelas 1 di SLB Negeri Balikpapan. Penelitian dilaksanakan dengan menggunakan metode Research and Development (R\&D) dengan melibatkan sampel sebanyak 7 siswa tunarungu pada jenjang SDLB Kelas 1 Tunarungu tahun ajaran 2019/2020. Data dianalisis dengan menggunakan pendekatan Single Subject Research (SSR). Hasil penelitian menunjukkan bahwa (1) pembelajaran menggunakan aplikasi GEMBIRA ini menjadi sangat fleksibel karena dapat dilakukan dimana saja serta kapan saja, (2) aplikasi GEMBIRA memudahkan guru dalam menemukan berbagai bunyi latar belakang sebagai media pembelajaran untuk melatihkan kompetensi mengenal bunyi latar belakang pada siswa tunarungu, (3) fitur yang menarik dalam aplikasi GEMBIRA meningkatkan motivasi dan minat belajar PKPBI siswa tunarungu jenjang SDLB kelas 1. Penelitian ini menunjukkan bahwa pemanfaatan media pembelajaran berbasis digital dapat memberikan manfaat bagi keberlangsungan proses pembelajaran yang lebih variatif.
\end{abstract}

Kata Kunci : aplikasi GEMBIRA; kepekaan bunyi dan suara; siswa tunarungu

\section{Abstract}

Learning compensatory programs for deaf students, namely the Development of Sound and Rhythm Perception Communication (PKPBI), are aimed at optimizing the potential of deaf students in the form of residual hearing sensitivity and vibration sensitivity. In an effort to train deaf students in optimizing the sensitivity of the residual hearing, creative learning media are needed, one of which is the GEMBIRA Application (Recognizing Variety of Sounds and Voices). This study aims to determine the use of the GEMBIRA application in training sensitivity to sound for grade 1 deaf elementary school students at SLB Negeri Balikpapan. The research was carried out using the Research and Development (R\&D) method involving a sample of 7 deaf students at the SDLB Class 1 Deaf level in the 
2019/2020 school year. The data were analyzed by Single Subject Research (SSR) approach. The results showed that (1) learning using the GEMBIRA application became very flexible because it could be done anywhere and anytime, (2) the GEMBIRA application made it easier for teachers to find various background sounds as a learning medium to practice competence in recognizing background sounds in deaf students, (3) an interesting feature in the GEMBIRA application increases the motivation and interest in learning PKPBI for grade 1 deaf students at SDLB level. This study shows that the use of digital-based learning media can provide benefits for the continuity of a more varied learning process.

Keywords: GEMBIRA application; sensitiveness against sound and voice; deaf students

\section{PENDAHULUAN}

Pembelajaran program kompensatoris atau program kekhususan merupakan program yang dirancang untuk memfasilitasi anak yang memiliki hambatan pada aspek tertentu seperti kehilangan fungsi penglihatan, pendengaran, wicara, gerak, maupun perilaku sehingga dapat dialihkan pada fungsi lain yang dapat menggantikan fungsi yang hilang. Hal ini dimaksudkan sebagai upaya mengoptimalkan potensi yang ada pada diri siswa/peserta didik. Sebagai contoh program kompensatoris bagi siswa dengan hambatan pendengaran atau tunarungu. Anak tunarungu merupakan anak yang mengalami hambatan dalam fungsi pendengarannya, sehingga diperlukan program yang dapat memaksimalkan sisa pendengaran yang dimiliki agar mampu dipergunakan sebaik-baiknya untuk berintegrasi dengan lingkungan yang penuh bunyi dan suara.

Walaupun anak tunarungu memiliki keterbatasan dalam aspek pendengaran, namun tetap dimungkinkan untuk diperkenalkan bunyi dan suara yang ada di sekeliling anak. Sejak tahun 1984 pembelajaran program kekhususan bagi siswa tunarungu yang dahulu bernama pelajaran Bina Persepsi Bunyi dan Irama (BPBI) telah dimasukkan ke dalam kurikulum sekolah luar biasa. Program ini merupakan program khusus yang wajib untuk diikuti peserta didik dari taman kanak-kanak sampai dengan jenjang sekolah menengah di SLB. Seiring berkembangnya pendidikan, pelaksanaan BPBI pun berubah menjadi program yang lebih komprehensif yakni Pengembangan Komunikasi Persepsi Bunyi dan Irama (PKPBI) bagi siswa tunarungu. PKPBI merupakan pembinaan komunikasi dan penghayatan bunyi yang dilakukan sengaja ataupun tidak sengaja, sehingga kemampuan peserta didik dalam hal 
komunikasi dan mempersepsi bunyi melalui pendengaran dan perasaan vibrasi yang masih dimiliki peserta didik tunarungu dapat berkembang secara optimal.

Program kompensatoris atau program khusus PKPBI akan berjalan secara maksimal apabila ditunjang dengan pemanfaatan media pembelajaran yang mampu mengakomodasi tujuan dari terlaksananya pembelajaran PKBI tersebut. Secara umum tujuan dari program PKPBI adalah agar kepekaan pendengaran dari siswa tunarungu dan perasaan vibrasi siswa dapat terlatih guna memahami dan merespons bunyi dan suara yang ada di sekeliling siswa baik dengan menggunakan Alat Bantu Dengar (ABD) maupun tidak, sehingga memungkinkan siswa tunarungu mampu beradaptasi dengan dunia bunyi di sekitarnya.

Materi dalam program PKPBI tersusun dari materi yang paling dasar sampai dengan yang paling komprehensif. Mulai dari penghayatan bunyi-bunyi latar belakang sampai dengan penghayatan bunyi yang paling kompleks, yakni bunyi bahasa hasil percakapan interaksi manusia. Sementara dalam praktiknya, program PKPBI dilalui berdasarkan tahapan-tahapan dari yang paling dasar sampai dengan yang paling kompleks yakni tahap deteksi bunyi, diskriminasi bunyi, identifikasi bunyi dan komprehensi. Dalam pelaksanaanya pun tidak boleh terlepas dari pengajaran bahasa, sehingga metode yang digunakan harus relevan dan mengakomodasi itu semua, didukung dengan pendekatan yang sesuai seperti pendekatan multisensoris, klasikal maupun individual dan sebagainya.

Berdasarkan uraian tentang pentingnya program khusus atau program PKPBI dan pemanfaatan aplikasi GEMBIRA dalam mendukung pembelajaran PKPBI, maka rumusan masalah dalam penelitian ini adalah "bagaimana pemanfaatan aplikasi GEMBIRA dalam melatih kepekaan terhadap bunyi dan suara bagi siswa tunarungu jenjang SDLB kelas 1? Sementara tujuan dari penelitian ini adalah memberikan alternatif media pembelajaran pengembangan komunikasi persepsi bunyi dan irama berbasis digital bagi siswa tunarungu.

Memandang bahwa pembelajaran PKPBI bagi siswa tunarungu menjadi hal yang sangat penting. karena didasarkan pada upaya untuk mengoptimalkan potensi yang ada pada siswa khususnya dalam hal kepekaan sisa pendengaran. Perancangan aplikasi GEMBIRA ini menjadi suatu inovasi yang dapat membantu mempermudah guru dalam mengenalkan berbagai bunyi latar belakang. Perancangan aplikasi ini memang dimaksudkan untuk merangkum suara dan bunyi yang ada di lingkungan sekitar, sehingga dapat memberikan pemahaman kepada siswa tunarungu bahwa di sekeliling siswa segala sesuatu memiliki bunyi dan bersuara. 
Pemanfaatan aplikasi GEMBIRA (Mengenal Ragam Bunyi dan Suara) ini juga dipergunakan sebagai alat bantu atau media dalam pembelajaran program kompensatoris Pengembangan Komunikasi Persepsi Bunyi dan Irama (PKPBI). Melalui pemanfaatan aplikasi GEMBIRA ini, diharapkan mampu memperkenalkan ragam bunyi dan suara yang ada di sekitar siswa. Disamping itu, melalui pemanfaatan aplikasi GEMBIRA ini mampu melatih siswa untuk meningkatkan kepekaan sisa pendengaran sehingga pada akhirnya siswa mampu beradaptasi dengan masyarakat di tengah dunia bunyi dan siswa tunarungu berkembang pengalamannya dalam mengenal ragam bunyi dan suara.

\section{KAJIAN PUSTAKA}

Boothroyd (dalam Bunawan \& Yuwati, 2000) menjelaskan bahwa penggunaan istilah tunarungu (hearing impairment) untuk menunjuk pada segala gangguan dalam daya dengar. Mangunsong (2009) menjelaskan bahwa anak tunarungu adalah mereka yang pendengarannya tidak berfungsi sehingga membutuhkan pelayanan pendidikan khusus. Kehilangan pendengaran cenderung menimbulkan masalah salah satunya adalah masalah komunikasi. Namun tak hanya berdampak pada komunikasi, kehilangan pendengaran cenderung berdampak pula pada aspek berbahasa hal ini disebabkan kurangnya pengalaman anak tunarungu dalam mendengar. Moores (dalam Hallahan dan Kauffman, 2006) mengutarakan definisi ketunarunguan merupakan kondisi dimana individu tidak mampu mendengar dan hal ini tampak dalam wicara atau bunyi-bunyian. Berdasarkan beberapa definisi yang dikemukakan oleh ahli di atas dapat disebutkan bahwa ketunarunguan merupakan kondisi kehilangan pendengaran dan memiliki dampak yang sangat besar dalam kehidupan seseorang utamanya dalam hal pemerolehan informasi, komunikasi, dan bahasa.

Program khusus bagi siswa tunarungu yang sebelumnya bernama Bina Komunikasi Persepsi Bunyi dan Irama merupakan program yang wajib diikuti oleh siswa tunarungu dari jenjang yang paling dasar (TKLB) sampai dengan sekolah menengah pertama (SMPLB). Penyelenggaraan pendidikan bagi siswa berkebutuhan khusus tidak boleh menitikberatkan pada ketidakmampuannya, namun harus memperhitungkan kompetensi yang masih mungkin untuk dikembangkan (Depdiknas, 2006). Depdiknas (2006) dalam buku Panduan Pelaksanaan Program Khusus, khususnya bagi siswa tunarungu, materi dalam Program Pengembangan Komunikasi Persepsi Bunyi dan Irama disusun secara berjenjang mulai dari penghayatan bunyi yang sifatnya paling dasar sampai dengan yang paling kompleks. Adapun bunyi-bunyian yang bisa diperkenalkan yakni antara lain bunyi latar belakang (alam, binatang), bunyi sebagai isyarat atau tanda (bunyi alat musik, bunyi kendaraan), dan 
bunyi bahasa yang terjadi saat ada interaksi antar manusia.

Penggunaan media dalam kegiatan belajar mengajar dimaksudkan untuk mempermudah dalam memahami materi dan isi dari materi dapat tersampaikan dengan baik. Media adalah segala alat fisik yang dapat menyajikan pesan serta merangsang siswa untuk belajar Briggs (dalam Sadiman, 2003). Dengan demikian dapat dikatakan peran media pembelajaran merupakan bagian integral dalam proses pembelajaran agar pembelajaran berjalan optimal dan mendukung tercapainya tujuan pembelajaran. Secara khusus, pengertian media dalam proses belajar mengajar cenderung diartikan sebagai alat-alat grafis, photografis, atau elektronik untuk menangkap, memproses, dan menyusun kembali informasi visual atau verbal (Arsyad, 2002). Bagi siswa tunarungu dalam upaya memberikan stimulus untuk mengoptimalkan potensi kepekaan sisa pendengaran bisa dipergunakan media stimulasi auditoris. Seperti mempergunakan alat musik atau recorder untuk mendengarkan rekaman bunyi-bunyian latar belakang atau sumber-sumber bunyi lainnya.

Suharsimi (2008) menyebutkan bahwa analisis kebutuhan diartikan sebagai suatu proses yang dilakukan oleh seseorang untuk mengidentifikasi kebutuhan sekaligus menentukan prioritasnya. Dalam penelitian ini, peneliti melakukan analisis kebutuhan akan pentingnya pemanfaatan media. Mengingat akan kebutuhan pembelajaran PKPBI bagi siswa tunarungu dan media pembelajaran yang menunjang maka dikembangkanlah aplikasi GEMBIRA. Melatihkan program PKPBI untuk mengoptimalkan kepekaan sisa pendengaran dan vibrasi siswa harus dilakukan secara kontinu dan terus menerus tak hanya terbatas saat pembelajaran di sekolah. Melalui pemanfaatan media pembelajaran digital ini, memungkinkan siswa tunarungu untuk tetap belajar dan melatih kepekaan inderanya dimana saja, kapan saja, dan dengan siapa saja (orang tua atau keluarga terdekat di rumah).

\section{METODE PENELITIAN}

Penelitian ini menggunakan pendekatan Research and Development (R\&D), untuk mengkaji beberapa aspek yang diperlukan untuk mengembangkan alat bantu mengajar program khusus bagi siswa tunarungu yakni pengembangan komunikasi persepsi bunyi dan irama. Menurut Borg \& Gall (dalam Sugiyono, 2010), metode Research and Development atau penelitian dan pengembangan adalah metode penelitian yang digunakan untuk menemukan dan mengembangkan (menghasilkan) produk tertentu, menguji keefektifan (validasi) produk tersebut. 
Sementara itu, penelitian ini juga dimaksudkan untuk memperoleh data yang diperlukan untuk melihat hasil ada tidaknya akibat dari suatu perlakuan (treatment). Sehingga penelitian ini juga menggunakan pendekatan penelitian dengan subjek tunggal untuk analisa datanya. Sunanto (2009) menjelaskan bahwa penelitian subjek tunggal bukan berarti eksperimen yang menggunakan satu orang subjek, namun bisa dua orang atau lebih. Penamaan subjek tunggal lebih menekankan pada cara penyajian dan analisis datanya yang didasarkan atas data individu.

Langkah-langkah penggunaan Metode Research and Development (R\&D) menurut Borg \& Gall (dalam Sugiyono, 2010) terdiri dari sepuluh langkah yang terdiri dari: potensi dan masalah, pengumpulan data, desain produk, validasi desain, revisi desain, ujicoba produk, revisi produk, ujicoba pemakaian, revisi produk, dan produksi massal. Penelitian pengembangan atau Research and Development (R\&D) merupakan sebuah strategi atau metode penelitian yang cukup ampuh untuk memperbaiki praktik. Berdasarkan beberapa definisi di atas dapat disimpulkan bahwa penelitian pengembangan adalah suatu langkah untuk mengembangkan suatu produk baru atau menyempurnakan produk yang sudah ada dan menguji keefektifannya, serta bersifat longitudinal atau bertahap dapat multy years.

Rancangan penelitian dalam penelitian ini baru dilaksanakan sampai pada 6 tahapan yakni: (1) melakukan analisis potensi dan masalah; (2) mengumpulkan data; (3) melakukan desain produk; (4) melakukan validasi desain; (5) melakukan revisi desain produk; dan (6) melakukan pencobaan terhadap penggunan produk. Pada tahapan pertama dilakukan analisis potensi dan masalah. Hal ini berangkat dari adanya potensi bahwa anak tunarungu masih memiliki potensi yang bisa dikembangkan, yakni kepekaan sisa pendengaran. Kemudian pemanfaatan gawai dalam menunjang media pembelajaran juga menjadi salah satu hal yang memiliki nilai tambah dalam proses pembelajaran berbasis digital. Sementara dari sudut pandang masalah dilihat bahwa pembelajaran dari rumah menjadi tantangan untuk bagaimana tetap mengajarkan program khusus (PKPBI) bagi siswa tunarungu.

Selanjutnya pada tahapan kedua yakni mengumpulkan data atau informasi. Hal yang dilakukan adalah mengumpulkan berbagai informasi yang dapat digunakan sebagai bahan untuk perencanaan produk. Seperti materi pembelajaran PKPBI pada siswa tunarungu jenjang SDLB kelas 1 tentang deteksi bunyi latar belakang. Segala hal yang berhubungan dengan perancangan produk seperti kemudahan materi, meliputi jenis-jenis sumber bunyi, dan komponen bunyi menjadi hal yang dikumpulkan dalam mendukung perancangan 
produk. Masuk pada tahapan desain produk yang harapannya produk tersebut dapat bermanfaat menunjang pelaksanaan pendidikan. Produk dari media pembelajaran yang dimaksud adalah media yang mendukung pembelajaran PKPBI berupa sebuah aplikasi. Aplikasi yang merangkum berbagai bunyi latar belakang dan sumber bunyi lainnya yang digunakan untuk melatih kepekaan sisa pendengaran bagi siswa tunarungu pada materi deteksi bunyi.

Validasi desain pada penelitian ini dilakukan sebagai upaya untuk menilai apakah rancangan produk, media pembelajaran ini efektif dalam pembelajaran PKPBI bagi siswa tunarungu. Validasi konten materi dalam media pembelajaran dilakukan oleh guru senior yang ahli dalam pembelajaran siswa tunarungu. Sementara validasi produk media baru dilakukan sebatas diskusi dengan guru TIK yang memiliki pengalaman dalam pengembangan TIK di SLB. Setelah melalui proses validasi dari beberapa ahli berkaitan dengan konten materi dan produk aplikasi, selanjutnya dilakukan revisi/perbaikan desain. Setelah ditemukan kelemahan, kemudian kelemahan tersebut diperbaiki dengan lebih menyederhanakan konten pada materinya menjadi tampilan awal, isi materi utama, dan latihan soal pada aplikasi yang akan dikembangkan.

Sehubungan dengan terbatasnya waktu penelitian, maka peneliti langsung melakukan pencobaan produk media pembelajaran dalam aktivitas pembelajaran bagi siswa tunarungu. Dalam aktivitas pembelajaran PKPBI, peneliti mencobakan media belajar berbasis aplikasi tersebut kepada siswa pada materi deteksi bunyi latar belakang. Sehubungan dengan mulainya masa pandemi di awal 2019, maka pencobaan aplikasi tersebut berlanjut dalam aktivitas belajar dari rumah. Sehingga dalam penggunaannya aplikasi GEMBIRA ini sudah dimanfaatkan untuk media belajar PKPBI tahap awal yakni deteksi suara.

Desain penelitian yang dipergunakan dalam penelitian ini adalah desain A-B. Desain A-B menurut Sunanto (2009) merupakan desain dasar dari penelitian subjek tunggal yang merujuk pada pengulangan pengukuran perilaku atau target behaviour pada dua kondisi yakni kondisi baseline (A) dan kondisi intervensi (B). Tujuan pengukuran baseline adalah memberikan deskripsi tingkah laku secara alamiah tanpa adanya treatment yang berfungsi sebagai landasan pembanding untuk penilaian keefektifan treatment, pengukuran baseline diambil untuk menciptakan suatu pola. Sementara treatment, merupakan gambaran mengenai kemampuan yang dimiliki subjek setelah diberikan perlakuan secara berulang. 


\section{HASIL PENELITIAN DAN PEMBAHASAN}

\section{Deskripsi Pengembangan Media}

Aplikasi GEMBIRA "Mengenal Ragam Bunyi dan Suara” merupakan sebuah aplikasi digital yang merangkum berbagai macam bunyi dan suara dari berbagai sumber bunyi seperti alam, manusia, isyarat atau tanda, dan binatang. Ragam bunyi dan suara juga gambar di dalam aplikasi ini diambil dari sumber pencarian gambar dalam Google. Aplikasi Gembira merupakan aplikasi hybrid dibuat dengan bahasa html, css, js dan framework 7 dan kompilasinya menggunakan SDK Android. Aplikasi GEMBIRA ini mampu support di smartphone dan laptop/PC dengan menggunakan aplikasi bantu. Aplikasi gembira ini terdiri dari beberapa tampilan yakni tampilan awal, tampilan konten/isi, tampilan latihan soal.

Pada bagian awal aplikasi GEMBIRA terdiri dari judul aplikasi dan beberapa point penting yang menggambarkan isi dari Aplikasi GEMBIRA. Bagian-bagian yang dimunculkan pada bagian awal aplikasi meliputi apa itu bunyi, sumber bunyi, dan latihan soal. Dalam materi yang terangkum dalam Aplikasi GEMBIRA terangkum berbagai bunyi dan suara yang bersumber dari bunyi latar belakang. Pada konten Sumber Bunyi peneliti memasukkan empat jenis bunyi/suara latar belakang yang bersumber dari alam, binatang, suara manusia, dan isyarat/tanda. Pada suara/bunyi yang terdapat dalam aplikasi GEMBIRA disertai dengan gambar, suara serta gambar animasi untuk memperjelas konsep kepada siswa menjadikannya semi konkret.

Gambar di bawah ini merupakan tampilan aplikasi GEMBIRA pada gawai peserta didik:
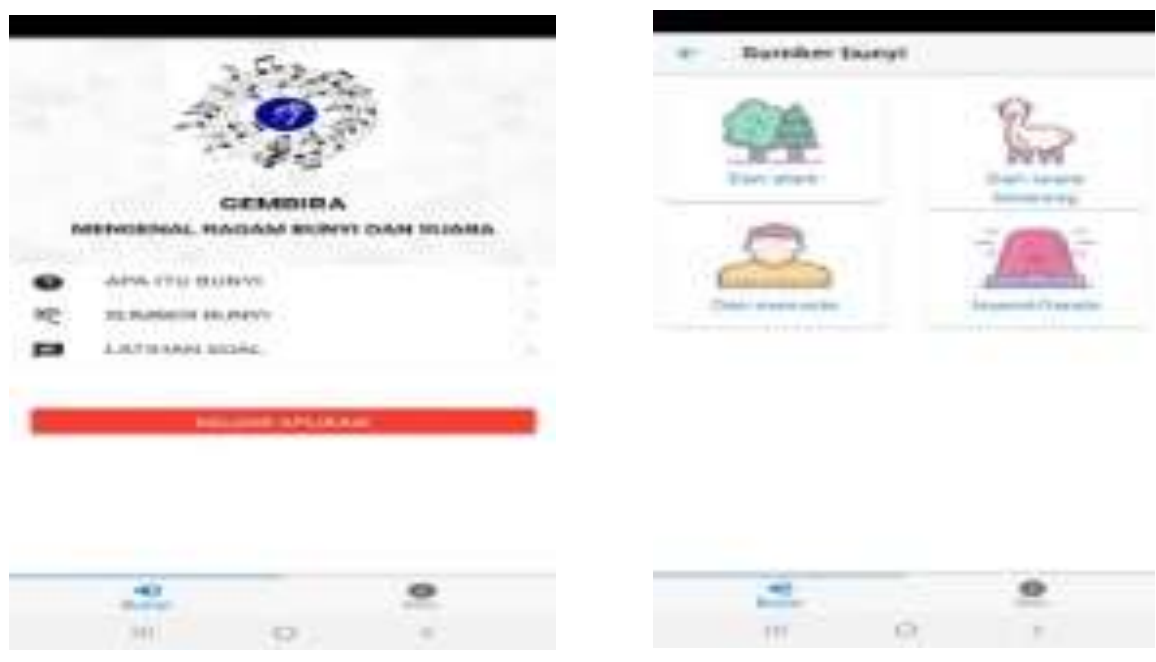

Gambar 1. Tampilan aplikasi GEMBIRA 
Untuk menjadikan pemahaman lebih komprehensif bagi siswa, Aplikasi GEMBIRA ini dilengkapi pula dengan latihan soal yang dapat dipergunakan siswa untuk menguatkan ingatan mereka kembali baik pada gambar maupun identifikasi bunyi/suara yang diperdengarkan. Latihan soal terbagi dua ada yang berupa kategori gambar dan kategori suara. Diberikan dua jenis latihan soal agar disamping anak mampu mendeteksi dan identifikasi bunyi yang diperdengarkan harapannya melalui gambar yang mereka lihat dapat meningkatkan kosakata mereka terhadap kata baru. Sehingga melalui perancangan aplikasi ini, dalam implementasinya bertujuan agar siswa tunarungu memiliki kesadaran akan bunyibunyian yang ada di sekitarnya.

Gambar berikut merupakan tampilan isi latihan soal pada aplikasi GEMBIRA:

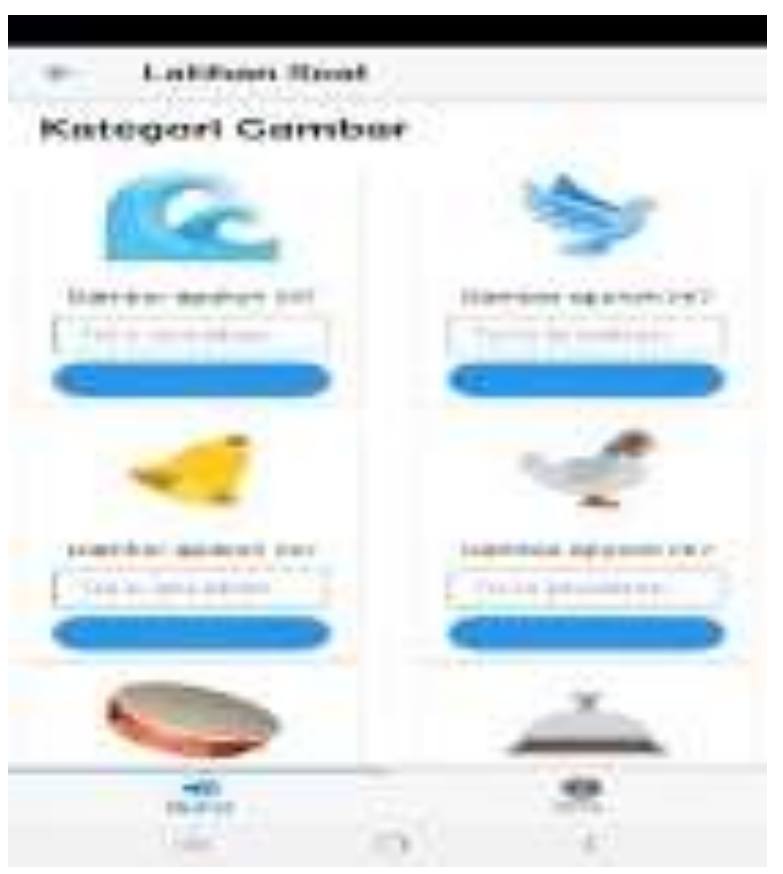

Gambar 2. Isi materi pada konten "Latihan Soal"

\section{Deskripsi Hasil Penelitian}

Langkah awal dalam menganalisa data penelitian ini adalah dengan melakukan pengumpulan data pemanfaatan aplikasi GEMBIRA dalam hal kemampuan hasil belajar PKPBI pada materi mendeteksi bunyi dan suara. Pengumpulan data ini diperoleh dari perlakuan awal baseline sebanyak 2 sesi (hari) dan treatment (perlakuan) sebanyak 4 sesi yang dilakukan secara berturut-turut semasa belajar dari rumah dengan menggunakan aplikasi GEMBIRA. Selanjutnya adalah menganalisa secara keseluruhan dari fase tersebut.

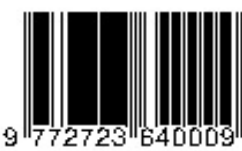


Teknik analisa data yang dipergunakan dalam penelitian ini adalah deskriptif kualitatif dengan analisa grafik. Data diperoleh dari hasil belajar siswa selama belajar dirumah dengan berpedoman hasil dokumentasi belajar siswa, serta wawancara tidak terstruktur dengan orangtua terhadap capaian belajar PKPBI selama dirumah menggunakan aplikasi GEMBIRA. Data yang terkumpul dibuat ke dalam bentuk grafik dan menganalisisnya. Kemudian dari hasil baseline dan treatment pada penggunaan aplikasi GEMBIRA dapat terlihat pada tabel dan grafik.

Berdasar pada data hasil pengukuran terhadap hasil belajar subjek dalam mendeteksi bunyi, pada kondisi baseline (A), treatment (B) ditampilkan dalam tabel berikut.

Tabel 1. Perkembangan hasil belajar kemampuan deteksi bunyi (A-B Design)

Keterangan:

\begin{tabular}{lccc}
\hline SUBJEK & A & B \\
\hline RK & $3 ; 4$ & $7 ; 8 ; 8 ; 9$ \\
FH & $3 ; 4$ & $6 ; 7 ; 7 ; 8$ \\
AD & $2 ; 3$ & $6 ; 6 ; 7 ; 7$ \\
AZ & $2 ; 3$ & $6 ; 7 ; 7 ; 8$ \\
KZ & $2 ; 4$ & $5 ; 6 ; 7 ; 7$ \\
SY & $3 ; 4$ & $7 ; 7 ; 8 ; 8$ \\
HO & $3 ; 4$ & $7 ; 8 ; 7 ; 9$ \\
\hline
\end{tabular}

A : Kondisi awal hasil belajar sebelum diberikan intervensi/treatment

B : Kondisi kemampuan hasil belajar setelah diberikan intervensi, dengan penggunaan aplikasi GEMBIRA

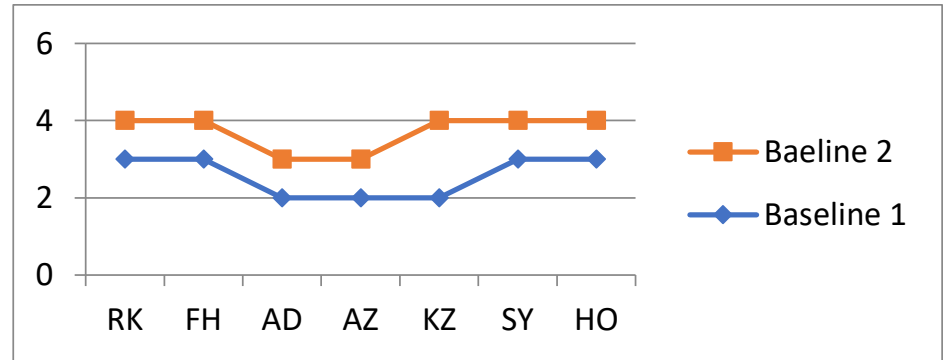

Gambar 3. Grafik Perkembangan Hasil Belajar Pada Kondisi Baseline (A)

Pada kondisi baseline (A), terdapat 2 sesi dengan pencapaian yang bervariasi dari masing-masing siswa. Kondisi awal sebelum pembelajaran dilatihkan mendeteksi bunyi dan suara yang diperdengarkan 10 macam suara secara bervariasi. Pada sesi pertama yang terlihat adalah kemampuan dasar awal terkait pemahaman tentang deteksi bunyi. Pada sesi kedua tampak peningkatan skor sebanyak satu. Kecenderungannya dengan senantiasa 
membiasakan siswa dengan bunyi maka muncul suatu kebiasaan untuk peka terhadap suara dan vibrasi. Kecenderungan arah grafik cenderung naik meskipun tidak stabil. Mean level pada baseline adalah 3,142. Sehingga pada baseline pertama rata-rata siswa mampu mendeteksi hanya 3 bunyi/suara yang diperdengarkan.

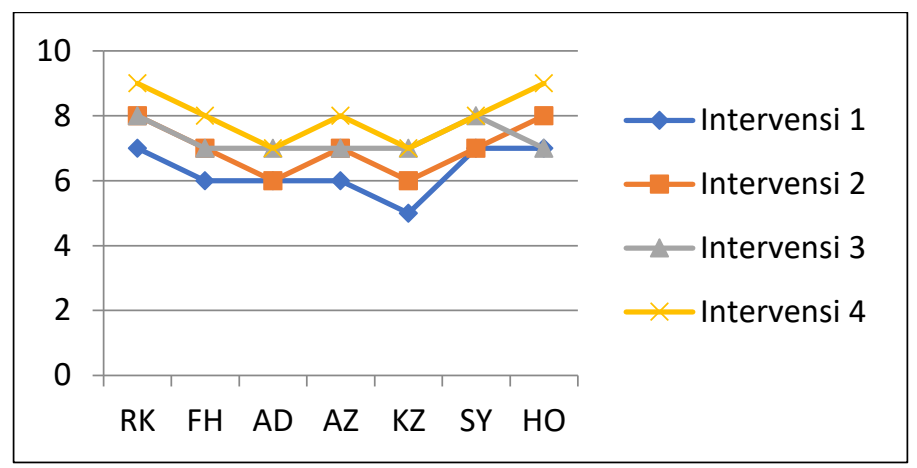

\section{Gambar 4. Grafik Perkembangan Hasil Belajar Pada Kondisi Treatment (B)}

Pada kondisi intervensi/treatment dilakukan sebanyak 4 kali atau 4 sesi secara berturut-turut. Adapun pencapaian skor pada setiap siswa berbeda-beda, namun kecenderunganya naik. Masing-masing siswa kecenderungannya pencapaian hasil belajarnya naik hal ini tampak pada grafik meskipun tidak stabil. Mean level pada treatment yakni 7,142 . Pada sesi intervensi tampak ada perubahan dari sesi pertama sampai dengan sesi keempat dengan rata-rata peningkatan sebanyak 1 angka. Dari perbandingan grafik diatas tampak terlihat adanya kecenderungan arah kondisi yang meningkat dari baseline (A) dan treatment/intervensi (B) . Hal ini menunjukkan adanya indikasi efektifnya pemanfaatan treatment dalam terhadap target behavior khususnya dalam hal deteksi bunyi.

Perbandingan antara rata-rata baseline (A) dengan treatmen (B) menunjukkan peningkatan dari nilai rata-rata 3,142 menjadi 7,142 . Hal ini bisa diartikan pada awalnya siswa tunarungu hanya mampu mendeteksi pada 3 sumber bunyi yang diperdengarkan, menggunakan treatmen/intervensi dengan aplikasi GEMBIRA siswa tunarungu mampu mendeteksi sampai dengan 7 sumber bunyi yang diperdengarkan. Hal ini menunjukkan adanya pengaruf positif dari pemanfaatan aplikasi GEMBIRA dalam melatihkan siswa akan deteksi bunyi dan suara sehingga mempengaruhi yang berimplikasi pada kepekaan bunyi dan suara siswa tunarungu.

Berdasarkan hasil analisis data meskipun secara umum grafik mengalami kenaikan namun kenaikan ini tidak stabil. Hal ini tentunya didasarkan akan banyak faktor antara lain dari faktor internal yakni sisa pendengaran yang memang dimiliki oleh siswa tunarungu dan 
derajat kehilangan pendengaran oleh masing-masing siswa yang berbeda. Selain itu peningkatan kemampuan deteksi bunyi sampai dengan pemahaman akan jenis bunyi apa dari yang didengar sekiranya masih memerlukan waktu yang sedikit lebih lama untuk mencapai perkembangan yang stabil.

Hasil penelitian yang membuktikan bahwa kegiatan belajar PKPBI dirumah menggunakan aplikasi GEMBIRA dapat meningkatkan kemampuan siswa dalam hal kepekaan terhadap bunyi dan suara untuk mendeteksi ada tidaknya bunyi. Pemanfaatan aplikasi GEMBIRA juga memberikan variasi berbeda dalam penggunaan media sehingga dapat meningkatkan aktivitas proses belajar menjadi lebih baik. Proses pembelajaran akan lebih menarik perhatian, sehingga dapat menumbuhkan motivasi belajar. Penggunaan aplikasi GEMBIRA menjadikan siswa memahami bahwa segala sesuatu yang ada di sekitar mereka memiliki bunyi/suara dan bisa dirasakan dengan mengandalkan kepekaan indera meraka terhadap suara dan vibrasi. Dengan bantuan gambar animasi yang menarik dan suara yang bisa disesuaikan volumenya menjadikan lebih jelas maknanya sehingga dapat lebih dipahami, yang pada akhirnya bermuara kepada terjadinya peningkatan hasil belajar.

Pembelajaran juga dinilai membantu mengoptimalkan kemampuan deteksi bunyi bagi siswa yang memang memiliki sisa pendengaran dan derajat kehilangan pedengaran yang tidak terlalu tinggi. Sementara untuk siswa yang lain pemanfaatan aplikasi ini dinilai baik untuk membantu untuk melatih dan membiasakan mereka beradaptasi dengan dunia suara. Peneliti melihat lebih jauh hasil belajar dan kemampuan siswa yang meningkat jauh lebih baik, motivasi belajar meningkat dan lebih menyenangkan dengan pemanfaatan aplikasi GEMBIRA ini utamanya dalam melatihkan kepekaan deteksi bunyi dan suara.

Sementara itu, keterbatasan dalam penelitian ini adalah, waktu yang sangat terbatas dan kondisi situasi yang tidak menungkinkan untuk berinteraksi secara langsung dan sering dalam menilai baseline dan melakukan intervensi disebabkan adanya pandemi COVID-19. Hal ini juga berdampak pada penilaian kemampuan awal dan pemberian intervensi yang dilakukan secara terbatas. Di samping itu penilaian hasil pembelajaran dilakukan melalui hasil dokumentasi dan wawancara tidak langsung dengan orangtua selama pembelajaran di rumah menggunakan aplikasi GEMBIRA. Sementara itu, dalam hal pengembangan produk, media pembelajaran ini belum diujicobakan sebelumnya mengingat terbatasnya waktu. 


\section{KESIMPULAN DAN SARAN}

\section{Kesimpulan}

Pembelajaran PKPBI (Pengembangan Komunikasi Persepsi Bunyi dan Irama) dengan materi deteksi bunyi dan suara dengan memanfaatkan aplikasi GEMBIRA selain dapat meningkatkan minat belajar, juga dapat memberikan pengalaman lebih bagi siswa tunarungu dalam mengenal sumber bunyi yang ada di sekitar. Melalui pemanfaatan aplikasi GEMBIRA, belajar PKPBI lebih menarik perhatian siswa, sehingga dapat menumbuhkan motivasi belajar dan melalui pemanfaatan media menjadikan materi yang diajarkan menjadi jelas maknanya. Sehingga dapat memperkaya pengalaman siswa dalam mengenal berbagai sumber bunyi.

Setelah melakukan penilaian akan kemampuan awal dan pemberian intervensi menggunakan aplikasi GEMBIRA, didapat hasil yang menunjukkan bahwa penggunaan media belajar aplikasi GEMBIRA dalam pembelajaran PKPBI mampu meningkatkan kepekaan dalam mengenal bunyi dan suara siswa tunarungu kelas 1 SDLB N Balikpapan. Hal ini dibuktikan dari hasil yang diperoleh setelah diberikan treatment terjadi peningkatan pemerolehan nilai. Pemerolehan rata-rata siswa pada tahap baseline dan treatment mengalami peningkatan, yakni 3,142 pada baseline menjadi 7,142 pada sesi treatment. Kondisi ini mengidentifikasikan adanya perubahan capaian nilai dan pemahaman pada target behaviour setelah diberikan perlakuan. Berdasarkan temuan tersebut dapat disimpulkan bahwa proses pembelajaran yang memanfaatkan penggunaan media belajar aplikasi GEMBIRA efektif diterapkan untuk melatih kepekaan siswa kelas 1 SDLB tunarungu untuk deteksi bunyi dan suara.

\section{Saran}

Media pembelajaran program kebutuhan khusus/PKPBI aplikasi GEMBIRA dapat digunakan untuk melatih juga meningkatkan kemampuan siswa tunarungu kelas 1 SDLB dalam hal deteksi bunyi dan suara serta memperkaya pengalaman siswa tunarungu dalam mengenal berbagai macam bunyi dan suara yang ada di sekitar mereka. Bagi peneliti kedepannya, perlu diperlakukan jenis penelitian yang sama dalam hal pengembangan media serta dengan menambah sesi pada kegiatan intervensi agar proses pembelajaran bisa maksimal dan peningkatan kemampuan siswa dapat berkembang secara optimal. 


\section{DAFTAR PUSTAKA}

Arikunto, S. (2008). Dasar-Dasar Evaluasi Pendidikan. Jakarta: Bumi Aksara

Arsyad, A. (2002). Media Pembelajaran. Jakarta: Raja Grafindo Persada.

Bunawan, L. \& Yuwati, C. S. (2000). Penguasaan Bahasa Anak Tunarungu. Jakarta: Yayasan Santi Rama

Departemen Pendidikan Nasional. (2006). Panduan Pelaksanaan Kurikulum Pendidikan Khusus SDLB Tunarungu. Jakarta: Direktorat Jendral Manajemen Pendidikan Dasar dan Menengah Direktorat Pembinaan Sekolah Luar Biasa.

Hallahan, D. P. \& Kauffman, J. M. (2006). Exceptional Learners: Introduction to Special Education 10th ed. USA: Pearson.

Krisnan. (2019). Pembelajaran Kompensatoris Bagi Anak Berkebutuhan Khusus (ABK). Diakses dari https://meenta.net/pembelajaran-kompensatoris-abk/, 1 Juli 2020

Mangunsong, F. (2009). Psikologi dan Pendidikan Anak Berkebutuhan Khusus. Jakarta: Lembaga Pengembangan Sarana Pengukuran dan Pendidikan Psikologi. Fakultas Psikologi Universitas Indonesia.

Sadiman, A. A. (2003). Media Pendidikan. Jakarta: Raja Grafindo Persada.

Sugiyono. (2010). Metode Penelitian Pendidikan Pendekatan Kuantitatif, Kualitatif dan $R \& D$. Bandung: Penerbit Alfabeta

Sunanto, J. (2009). Pendekatan Penelitian dalam Bidang Pendidikan Luar Biasa. Surakarta: Makalah Siposium Internasional dan Temu Ilmiah Nasional.

Sunanto, J., Takeuchi, K., \& Nakata, H. (2006). Pengantar Penelitian dengan Subjek Tunggal. Tsukuba: Centre for Research on International Cooperation in Educational Development (CRICED), University of Tsukuba 